\title{
Analysis on the Intercultural Communication Strategy of Chinese Traditional Culture
}

\author{
Qixin Zhang \\ Hunan University \\ Changsha, China
}

\begin{abstract}
Excellent and profound traditional culture of China is the soft power that support Chinese nation in standing in the world. Under the social co-ordination of modern society, it is an important issue to innovate the mode of international communication of Chinese traditional culture and spread the excellent Chinese traditional culture to show the unique charm of the traditional Chinese culture in the global culture exchange, which needs to start with enhancing communication capability of Chinese culture, creating a platform for Internet communications and building a new cultural transmission and image symbols. This article focuses on the study on strategy of international communication of Chinese traditional culture.
\end{abstract}

Keywords - traditional culture; international communication; communication strategy

\section{INTRODUCTION}

The international communication of Chinese traditional culture should not only show the profound historical and cultural background of China to the world truthfully, accurately, comprehensively and objectively, but also show the achievements of China in modern society, and the state of its ideology and behavioral pattern, so that people abroad can know a healthy China, and understand and accept a pluralistic and open China, and China can better go global and integrate into the world.

\section{THE CONNOTATION OF CHINESE TRADITIONAL CULTURE}

Chinese traditional culture involves wide range with deep connotations. Many people equate Chinese traditional culture with Confucianism, which is a one-sided understanding of Chinese traditional culture. Chinese traditional culture is a national culture that evolves from Chinese civilization and can display the characteristics and appearance of the nation. It is an overall representation of different ideological cultures, concepts and forms in the national history. Specifically, it refers to the traditional culture with distinctive national characteristics that is created by ancestors living in the Chinese region for generations and inherited and developed by the Chinese nation. To be specific, Chinese traditional culture includes the hundred schools of thought, lyre-playing, chess, calligraphy and painting, traditional literature, traditional festivals, Chinese drama, Chinese architecture, Chinese and characters, traditional Chinese medicine, religious philosophy, folk crafts, Chinese martial arts, regional culture, headdress and costumes, antiques, legend myths, and traditional music and so on.

\section{SIGNIFICANCE OF INTERNATIONAL COMMUNICATION of Chinese TRADITIONAL CULTURE}

\section{A. To Show the Charm of Chinese Culture}

In the environment of rapidly global economy development, the enthusiasm, means and content of the communication of Chinese culture are unprecedented. However, query and misunderstandings about Chinese culture from various parties in the world still exist. In the eyes of Western media, China is often misunderstood as "strong" and "offensive". Political official actions of China are always distorted and queried as well. The international communication of Chinese traditional culture can truly demonstrate the charm of Chinese culture and make the image of China realer and more vivid. The spread of Chinese traditional culture will bring about qualitative changes. The intercultural communication will bring about changes in China's external image. The masses of other countries will make more objective and accurate assessments of China. [1] For example, "the Belt and Road" strategy proposed by President Xi Jinping in 2013 takes the economic cooperation and economic development as foundation to promote cultural exchanges among all countries along the Silk Road so as to create a deeper impression in all countries in the economic belt. They will also form a more profound understanding to the connotation of Chinese culture. The implementation of the "Belt and Road" economic strategy is based on economic construction to promote the international communication of Chinese traditional culture, which can fully demonstrate the charm of Chinese traditional culture, so that they can understand Chinese material and spiritual culture and form a completely new impression on China.

\section{B. To Spread Chinese Value Idea}

The state itself is a cultural organization, and there must be elements of cultural exchange in the diplomatic relations between countries. Cultural tie is the basis and foundation of diplomacy. No matter in western countries or in east countries, culture occupies an irreplaceable role in the formation and development of the country no matter at present or in the past. There is an inherent, close and inevitable connection between culture and nation. Cultural 
identity and acceptance can further strengthen and consolidate national identity and national identity. The state can also promote cultural publicity by means of government resources and administration to guide cultural identity, and then realize the imitation and follow-up of cultures of other countries. International cultural communication is an important variable of national soft power. Since culture possesses the characteristic of taking values as core, the influence of culture on the cognitive subject is invisible and soft. Culture can play a special role in the international communications, and change the human's thinking mode by virtue of subtle influence. In recent years, China presents in the world with a new look, new cultural opportunities, and new connotation. "Made in China" also swept the world. 4G technology, high-speed rail technology, nuclear power technology and new energy technology have transformed the image of low-end industries in China in the past and formed a completely new growth mechanism. Xi Jinping set a great image of friendship and mutual assistance when meeting Putin at the initial stage of Sochi Winter Olympics, which strengthened the national affinity of China.

\section{To Enhance the Strategic Positioning of International Communication}

The spread of Chinese traditional culture is closely linked with the establishment of the national image. From the perspective of strengthening cultural soft power, the main purpose of the sovereign countries in proactively opening up the international cultural exchanges is to seek the emulation of other country to their own culture through cultural communication and cultural identification so as to enhance the attractiveness of the country and strive for cooperation and follow of other countries when the country implements external explosion. The initial motivation for building a national image is to improve the country's image. On this basis, we should strengthen the attractiveness and charisma of the country in order to strengthen the soft power and reputation of the country. The national reputation is the positive evaluation and positive recognition of the country made by international community based on the understanding of the country. The national reputation is the demand of the country's revitalization. In the the process of forming national reputation, strengthening the national charisma and attraction, communication of Chinese traditional culture plays an important role. At present, China's economy has entered a phase of new normal development and achieved rapid and steady development. The mode of economic growth has also gradually shifted from extensive to intensive growth, and the mode of investment has gradually shifted from element-driven to innovation-driven. The excellent economic environment provides an opportunity for China's foreign cooperation. The effective communication of culture has laid the foundation for China to establish good neighborly and friendly relations and can further enhance the strategic positioning of international communication.

\section{THE STRATEGY FOR INTERNATIONAL COMMUNiCATION OF CHINESE TRADITIONAL CUlTuRE}

\section{A. To Enhance the Communication Capability of Chinese Culture}

The communication capability of Chinese culture is an important part of the soft power of Chinese culture. In the process of international communication of Chinese traditional culture, it is crucial to attach importance to the promotion of the communication capability of Chinese culture, which will directly influence the effect of China's international communication. The promotion of communication capability of traditional Chinese culture can be started from the following aspects:

1) To establish cultural self-confidence and promote cultural harmony: For a long time, due to the influence of external environment and internal factors, people's cognition of their own traditional culture has always been in the swinging extreme. They often plunge into the two extremes of cultural arrogance and inferiority, which led to the ambiguous cultural orientation. General Secretary Xi Jinping clearly pointed out in the 19th CPC National Congress report that it is necessary to strengthen cultural confidence and promote the prosperity and development of socialist culture. Without a high degree of cultural confidence, there is no cultural prosperity, let alone great rejuvenation of the Chinese nation. From the middle of the 19 th century to the 21 st century, Chinese culture was influenced by the Western world view for more than two centuries. It believed that Western culture possesses its inherent advantages and we should abandon Chinese traditional old culture. This colonialist cultural concept still affects people's cultural self-confidence. Therefore, to break this constraint, we need to break the Western Centrism theory and objectively understand the contributions made by different kinds of cultures in the history of human development. Therefore, to achieve international communication, Chinese traditional culture must be confident, open and full of generosity. Based on showing affinity and inclusiveness, Chinese traditional culture should collide and exchange with cultures of other countries in an equal and shared form and comprehensively implement cultural transmission.

2) To interpret Chinese dream and show Chinese spirit: Chinese dream is the concentrated embodiment of Chinese culture as well as a manifestation integrating the essence of Chinese culture. Chinese dream can show the world the Chinese culture that embodies the energetic, brave and industrious spirit of Chinese people. Chinese dream is a self-strengthening dream as well as rejuvenation dream. The national pride of Chinese civilization has repeatedly been trampled by the Western powers for centuries, but national pride still tenaciously survives in the deep heart of the Chinese people. This cultural gene directly determines that Chinese nation must rely on its industrious hands to step on 
the road to rejuvenation. Chinese dream is the key element in the spread of Chinese traditional culture and is of great importance to the spread of Chinese traditional culture. In the process of building Chinese dream, we should uncover the spiritual characteristics behind the story and show the form of traditional Chinese culture to people around the world.

3) To spread Chinese value and realize value identification: Value is the core of culture, which represents the most basic characteristics of culture, shows the widest consensus of society and gathers the deep pursuit of the nation. The most fundamental goal of promoting the communication capability of Chinese traditional culture and expanding the world's influence of Chinese traditional culture is to pay attention to the international communication of the socialist core values and highlight the value connotation of Chinese traditional culture. China influences the development of the world in the modern global economic environment. The attention that has been attracted is due to the important influence of economic development of China on the surrounding areas and countries. The socialist road with Chinese characteristics opened up by socialist value outlook is not only result in the rise of China, but also a brand new way of thinking and development road. Therefore, in the process of international communication of Chinese traditional culture, we should not only talk about China's long historical tradition and folk culture, but also pay more attention to the significance of the socialist core values to China, cast China's core values into the world and further highlight the importance of China's development for the world, which is an important way to achieve value recognition.

4) To create a cultural brand and enhance the country's image: Whether in the field of culture or in other fields, the establishment of international brands with significant influence plays an important role in enhancing the strength of own cultural communication and shaping a sound and healthy national image. The brand is not only the representative of the product, but also the symbol of national spirit and national culture. For example, Hollywood movie brand of the United States is the most typical representative of Americans pursuing art and freedom. Chinese cultural characteristics have yet to be interpreted by the Chinese brand with world influence. Although there are already some world famous brands in China, the brand strategy is still confined to the industry and the market. There is no conscious combination of the brand's influence with the positive image of Chinese traditional culture. To create a positive and healthy image, China not only needs to rely on simple advocacy but also need to rely on a long-term and comprehensive strategic plan. To build a culture brand and enhance the national image, it is necessary to strengthen the sense of solidarity and self-awareness of Chinese brands, promote the enterprises integrate the spirit of Chinese traditional culture in the practice of brand strategy and consciously shape the brand image suitable for the global market with characteristics of Chinese traditional culture.

\section{B. To Create Cultural Communication Platform Based on the Internet}

At present, China has entered the era of "Internet + " and the relationship between Internet industry and economic development is very close. In the process of international communication of Chinese traditional culture, it is also necessary to rely on internet platform technology and make use of scientific and technological innovation ability to promote the full-scale communication of culture. First, we should establish a database of cultural sites. There are a large number of foreign websites in Chinese culture, including various websites related to artistic performance and circulation of art products. In international communication of culture based on the Internet platform, we should strengthen the links among websites to make them develop by borrowing force each other, jointly establish an authoritative database of Chinese traditional culture in an all-round way, achieve the connection of the cluster of Chinese cultural websites, and construct multi-disciplinary projects to show more comprehensive information on Chinese traditional culture. Second, we can develop Internet cultural terminal applications. Mobile devices and mobile applications are all important ways of information communication in the Internet + era. The international communication of Chinese traditional culture can also be achieved through the development of an Internet culture terminal. For example, Chinese culture website developed mobile device application software that "touches Chinese culture" and promoted it in Android systems and ios systems, so it has a high degree of popularity. In the process of future development of Internet cultural terminal applications, we should strengthen the added value of economic interests and the surrounding industrial clusters based on the enrichment of their own cultural content, and look for fixed audience and communication target to strengthen the publicity effect of traditional culture. With the mature development of the application of website cluster terminal, LBS (location based service) positioning service system can also be used. According to the geographical area where the user is located, the geographic and natural information, folk customs, surrounding cultural service venues and ancillary facilities are displayed actively, allowing users to quickly locate the local attractions and specialty restaurants through LBS location service system. Finally is promotion of social media. The construction of China traditional culture communication website needs to be designed according to the interests and hobbies of the target countries and the demand for Chinese culture. The construction of the website for international communication of Chinese traditional culture can draw lessons from the construction of similar well-known international websites. It can learn from advanced experience from the construction of well-known overseas cultural communication websites, pay attention to the details of website design, and refine the service in the foreign audience experience service-side links to allow users to easily accept the communication of Chinese traditional culture according to their own needs. In the content setting module, the 
corresponding blank space can be set between different contents, texts and images according to the reading habit of western readers, so that the division between different functional areas is clearer and the layout is reasonable, so the foreign audiences can accurately obtain what they want to read. In terms of functional experience, we can include entrances and advertisements of famous international exchange media in website design, and add forums for users' comments and exchanges so that users can interact with likeminded people in the cultural sections that they are interested in.

\section{To Build a New Cultural Transmission and Image Symbols}

The report of the 19th National Congress of the Communist Party of China pointed out: we should strengthen cultural confidence since cultural confidence is the historical traditions of the party, the country and the national culture, value connotation, understanding and recognition of practical significance and the belief built based on this, as well as the power to obtain the great victory of socialism with Chinese characteristics. To promote the communicating effect of international communication of traditional Chinese culture, it is necessary to build a new image of Chinese traditional culture and create a new symbol of traditional cultural communication.

1) To create a new image symbol through the material culture: Material culture covers the material culture and material consumption culture. In the process of international communication of traditional culture and achieving a new image symbol, material consumption culture is the key communication content. For the international public, the initial perception of China is also closely related to materialconsumption culture, such as Chinese restaurants that have been opened around the world, toys and clothing made by the world's factories. We can spread the Chinese traditional culture by starting with the material consumption culture. First, we can spread a balanced food culture. Food culture is the culture formed in the process of food production and consumption, and has close connection with the life of people all over the world. In Chinese traditional culture, food culture is based on moral values, social values and values, which are mainly represented by balance and health maintenance. This is the arrangement of Chinese food culture as well as the connotation of Chinese food culture [3]. Chinese people pay more attention to family values in their diets. They like to share things with family and talk about everything in a cheerful atmosphere. This is the balanced food culture in China. By spreading the balanced food culture of China, we can let people in different countries feel that pursuit of harmony is Chinese nature in the process of tasting Chinese cuisine. Second, we can spread the tolerant and elegant clothing culture. The clothing culture of Chinese traditional culture is the initial effect of shaping the national image. Clothing is the primary impression that the country gives to the public. The communication of traditional clothing culture is to spread the country's spiritual style and way of life. We must uphold the traditional ethnic clothing features. The clothing culture in Chinese traditional culture is extensive and profound. The Han Chinese Clothing of Han Dynasty, the cheongsam during the Republic of China and the traditional costumes of ethnic minorities are the representatives of clothing in Chinese traditional culture. Chinese traditional clothing covers and contains everything, and has different forms, fully demonstrating the characteristics of the inclusive and open nature of Chinese traditional culture. In the process of communication of traditional culture, we should show an open and inclusive modern China by spreading an open and inclusive clothing culture.

2) To create a new symbol of the image through spiritual culture: Spiritual culture covers a wide range, including knowledge, ideas, norms, and folklore and so on. The core of spiritual culture is the standard of value. In the process of international communication of Chinese traditional culture, the purpose can be realized through spreading tourism culture and sports culture. First, we can spread Chinese traditional culture through tourism. Attracting foreign tourists and carrying forward the excellent culture of the people to establish a healthy national image is a commonly used method in all countries in the world. Considering the actual situation of China, we should integrate tourism planning and shaping the national image of peaceful development in the process of tourism and cultural communication, and use the rich and diversified tourism resources to demonstrate the open, tolerant and harmonious cultural core of China. Second, we can spread Chinese traditional culture through sports. Sports are an important part of popular culture as well as an effective way to shape the country's image and spread it to other countries. Chinese sports culture pursues the harmony between man and nature, pursues the unity of man and nature, and lay emphasis on natural development, which coincides with the sustainable development and harmonious society advocated by contemporary Chinese society. This shows that China has been the country that pursues peace since ancient times. We can make use of the flexibility and permeability of Chinese sports culture to spread the strategic culture of China such as peace, opening up and tolerance so that the international public can feel the broad mind and peaceful development ideas of the Chinese nation to further shape China's international image of peace, development, tolerance and openness.

\section{CONCLUSION}

In the course of conflicts and interactions between different civilizations in the world, the national society and the international public also look forward to further understanding China. The vastness and cultural charm that are embedded in Chinese traditional culture are the foundation of the Chinese nation to pass the flame down from generation to generation as well as the power that 
China contributes to the world. In the process of international communication of Chinese traditional culture, we must innovate and open up to spread Chinese traditional culture so that Chinese traditional culture can go out and live.

\section{REFERENCES}

[1] Zhong Yuping. The Construction of Traditional Culture in International Communication - Taking Chengdu as an Example. Voice screen world, 2013, (10), 25-27.

[2] Tan Shuqian. Influence of Teaching Chinese as a Second Language on Chinese Culture Communication and Analysis of its Function, 2015, (02), 146.

[3] Liu Xin. The Strategy of international communication of Chinese Traditional Sports Culture under the Disadvantage Condition Taking Chinese Wushu as an Example. journal of physical education, 2009, (01), 88-90 